\title{
Causation in Environmental Offense
}

\author{
Mahrus Ali ${ }^{1 *}$ \\ ${ }^{I}$ Department of Criminal Law, Universitas Islam Indonesia, Yogyakarta, Indonesia \\ *Corresponding author. Email: mahrus_ali@uii.ac.id
}

\begin{abstract}
This study is aimed at analyzing the inadequacy of theories on causality in criminal law to be applied to the offenses of environmental damage/pollution, and ideas about its use in relation to characteristic of environmental offense. This study belongs to normative legal research using the statutory, philosophical, and conceptual approaches. The study reveals that today, the environmental is philosophically placed both as a legal interest and victim of crime. Such crimes can directly threat or harm the environment. The environmental damage or pollution also threatens the rights of future generations to enjoy clean and healthy environment as an impact of principle of ubiquity. The amount of environmental damage is also difficult to calculate and the time span can occur decades later after the crime was committed. Therefore, the proof of causality must shift from the proof of factual consequences to the proof of effect under the basis of prediction of scientific knowledge. The transformation of scientific evidence into legal evidence is the main key in proving emerge of environmental damage/pollution.
\end{abstract}

Keywords: environmental offense, causation, scientific evidence, legal evidence

\section{INTRODUCTION}

Causality is one of the most complex issues, both at the philosophical level and in the criminal law discourse [1]. This issue presents an important role to determine which actions are regarded as the cause of the emergence of the results that are prohibited by law, and then who is criminally responsible for an act. Both of these are closely correlated with the validity of criminal convictions by judges.

The theoretical discourse on causality that evolves in the civil law system includes condition sine qua non-theory, generalization theory, individualization theory, subjective and objective adequate theory, and relevance theory [2]. Even though these theories have different views in determining an action as a cause for the emerging of a result, however, the results must occur. If the consequences have not yet arisen or emerged, then theories of causality are not able to be used. In short, the application/exercise of these theories is post-factum.

The need to prove the result is problematic when it is applied to environmental offenses. The emergence of environmental damage/pollution is mostly known after a few years later after the prohibited acts were conducted [3]. In environmental offenses, there is a different time span between conduct is committed and the result of the action has emerged. If it still refers to the above theories of causality, this is diametrically opposed to the objective of environmental legislation that seeks to reduce or prevent pollution/environmental damage [4]. Therefore, the legal issues in this research focus on the reasons that become the basis of the need to shift the proof of causality in environmental offenses, and the idea of its application in the offense of environmental damage/pollution.

\section{METHOD}

This research is normative legal research and conducted with a statutory, philosophical, and conceptual approach. The first approach is specifically used to examine offenses by result in article 98 section (1) and 99 section (1) of the Law on Environmental Protection and Management. The second approach is used to examine values underlying the shift in causality. The final approach is related to the current doctrine that develops in environmental criminal law. The research findings were analyzed qualitatively through data reduction, presenting data, and conclusion.

\section{RESULT AND DISCUSSION}

\subsection{Reasons for shifting causality}

Crimes that require the proof of causality include result crime, crime qualified by the result, and result crime by omission [5]. In the Law number 30 of 2009, article 98 section (1) stated that "any person who intentionally commits violation (wrongdoing) that exceeds the ambient limit of standard of air quality, water quality, seawater quality, or the standard criteria of environmental damage..." and Article 99 section (1) whose the provision stated that "any person because of being negligent causes the exceeding of the limit of ambient standard of air quality, water quality, seawater quality, or the standard criteria of environmental damage...". These offenses require causation.

The results in the form of "exceeding ambient air, water, and seawater quality standard" or "exceeding environmental damage criteria" must be caused by an 
individual or corporate, whether intentionally or negligent. The environmental quality standard is a measurement of the limits or levels of living things, substances, energy, or components that exist or must be present, and/or pollutant elements which are tolerated in certain resources as environmental elements. If the environmental quality standards are exceeded, then environmental pollution occurs. The standard criterion for environmental damage according to Article 1 point 15 is the size limit of changes in physical, chemical, and/or biological characteristics of the environment that can be tolerated by the environment in order to be able to preserve its functions. If the environmental criteria are damaged, environmental damage occurs, namely direct and/or indirect changes to the physical, chemical, and/or biological nature of the environment that exceeds the standard environmental damage criteria. The meaning of the action can be various, as long as it is actively conducted through bodily movements and is a cause for environmental pollution.

The provision which requires any result in determining the occurrence of an offense actually contradicts the current trends in environmental criminal law. Today, the environment has been placed as a legal interest and as a victim of crime [6]. This is the impact of the view that humans must obey nature (the environment) [7]. This has implications for the meaning of extended environmental losses, not only losses suffered by a human, but also the physical losses of the environment itself, such as land, minerals, fire, birds, and fish, also the threat of harm [8]. Specific environmental losses are threat damage and degradation of ecosystems, species extinction, climate change, global warming, environmental pollution, and losses to animals [9].

The need to prove causality in environmental offence requires to have environmental damage/pollution at first. This view is crucial and dangerous for the survival of the environment, ecosystems, and human. In certain contexts, environmental damage/pollution cannot be restored, even by using sophisticated technology. When environment is damaged or polluted, it will be difficult or even impossible to be recovered [10]. The right of future generations to enjoy a healthy and clean environment has also been abused, and they are likely to die. In fact, the right must not be reduced at all [11], as a result of the internalization of inter-generational equity theory [12]. This theory is used as an ethical principle in demanding justice and balance between current and future generations and placed as a central concept in sustainable development [13].

All generations are partners in treating and utilizing the earth. Every generation needs to treat the earth, natural resources, and culture, at least, well, like when humans received it for the first time. This arises three principles in inter-generational justice theory, namely choice, quality, and access. Choice means that the current generation is obliged to treat the diversity of natural resources so that future generations can use it to meet their needs. Quality is defined as the certainty of the quality of environmental balance that can be compared between one generation and the next. Access is defined as access that can be compared. There is no discriminatory access between generations, to enjoy and treat the earth and the natural resources in it [14].
Environmental offenses are also categorized as malum in se crime. Individuals whose actions spread B3 waste into the environment, which causes environmental pollution, is still considered as a crime, even if legal permit from the government has been obtained. This action is considered an unethical and immoral act. The act is still considered a crime, even though environmental pollution arises later. Victims of environmental offenses also cannot be calculated and the distance of losses can appear years later, since the beginning of the offense. The location of the prohibited act and the environmental loss can also be different (principle of ubiquity) [15]. In addition, hazardous and toxic materials that are spread into the air without going through safety procedures and processes for the environment increase the incidence of respiratory diseases and reduce the overall quality of the earth's atmosphere. The result can be felt long after the actor spreads these materials [16]. If it constantly keeps that a result must arise in advance in order to prove causality, then more victims, both environmental and human, will not be saved. The shift in causality is precisely to prevent further damage/pollution to the environment [17].

\subsection{Applying Scientific Prediction-Based Causation on Environmental Offense}

The proving of scientific prediction-based causality is conducted through the empowerment of scientific evidence. In the case of environmental pollution/damage, scientific evidence through laboratory research has a very important role because it is able to prove that the environmental damage/pollution has arisen due to the actions of a person or corporation. In the case of Kalista Alam, Ltd as a defendant, laboratory research conducted by environmental experts, Bambang Hero Saharjo, has proven that the hot spot data detected in the burnt area that has been planted with oil palm appears to be clustered, particularly on the cleared and worked on the land. In addition, fires also occurred in certain periods and recur in 2009, 2010, 2011 and 2012. Therefore, fires occurred in the palm oil plantation area of Kalista, Ltd is a result of intentional conduct [18].

Scientific evidence is also used in all cases of environmental pollution. To assess whether the quality standards have been polluted or not, or whether the environment has been damaged or not, it depends on scientific evidence. The results of scientific evidence are then transformed into legal evidence. Based on article 96 of the Law, scientific evidence can be categorized both as expert statement and letter. Laboratory test results in regard to the environmental damage/pollution committed by individual or corporation intentionally or negligently is an evidence of a letter. To clarify and make it easier for judges to understand laboratory results, an expert statement is needed to explain and becomes as an expert statement. In the context of the system of evidence, scientific evidence in an environmental case, which has been transformed into legal evidence, thus fulfills a minimum of two kinds of evidence for convicting crimes as promulgated in article 183 of the Code of Criminal Procedure. 
[2] A. Sofian, Ajaran Kausalitas dalam RKUHP, Institute for Criminal Justice Reform, Aliansi RUU KUHP, Binus University, Jakarta, 2016, p. 1

[3] H. Qudah, Towards International Criminalization of Trans boundary Environmental Crimes, Dissertation, Pace Law School, New York, 2014, p. 71

[4] T. O. McGarity, "The Goals of Environmental Legislation", Boston College Environmental Affairs Law Review, 31, 2004, p. 529

[5] A. Sofian, Ajaran Kausalitas Hukum Pidana, Prenada Media, Jakarta, 2018

[6] M. Hall, "Environmental Harm and Environmental Victims Scouping Out a Green Victimology", International Review of Victimology, 20, 2014, pp. $129-143$

[7] M.C. Wood, Nature's Trust Environmental Law for a New Ecological Age, Cambridge University Press, New York, 2014, p. 6

[8] M. Faure \& J. Liu, "New Models for the Compensation of Natural Resources", Kentucky Journal of Equine, Agriculture, and Natural Resources Law, 4, 2011-2012, p. 261-262

[9] J. G. Laitos, "Standing and Environmental Harm: The Double Paradox", Virginia Environmental Law Journal, 31, 2013, pp. 67-71

[10] C. R. Sunstein, "Irreversible and Catastrophic", Cornell Law Review, 91, 2006, pp. 860-863

[11] B. Boer, "Institutionalizing Ecologically Sustainable Development: The Roles of National, State, and Local Governments in Translating Grand Strategy into Action", Willamette Law Review, 31, 1995, p. 319; R. Maguire, "Incorporating International Environmental Legal Principle into Future Climate Change", Carbon \& Climate Law Review, 6, 2012, p. 105

[12] J. C. Wood, "Intergenerational Equity and Climate Change", Georgetown International Environmental Law Review, 8, 1996, p. 299

[13] W. K. Sung, "Core Issues in International Sustainable Development: Analysis of Shifting Priorities at U.N. Environmental Conferences", Environmental Law Reporter News \& Analysis, 44, 2014, p. 10585.

[14] E. B. Weiss, "Climate Change, Intergenerational Equity and International Law", Vermont Journal of Environmental Law, 9, 2008, p. 616
[1] M. C. Materni, "Rebooting the Discourse on Causation in the Criminal Law: A Pragmatic (and Imperfect) Approach", Criminal Law Bulletin, 50, 6, 2014 
[17] N. Pellegrino, “A Gap in Causation? Punishing Polluters for Contributing to Climate Change \& Increasing Violent Crime", Pace Environmental Law Review, 2018, p. 390

[18] Court decision number: 1554 K/Pid.Sus/2015, p.4. 